\title{
MINING
}

UDC $622.281(574.32)$

V.F. Diomin ${ }^{1}$, Dr. Sc. (Tech.), Prof., orcid.org/0000-0002-1718-856X, E. R. Khalikova ${ }^{1}$, orcid.org/0000-0003-1501-8492, T.V.Diomina ${ }^{2}$, Cand. Sc. (Tech.), orcid.org/0000-0002-0042-7886, V.V.Zhurov ${ }^{1}$, Cand. Sc. (Tech.), orcid.org/0000-0002-4413-8584 https://doi.org/10.29202/nvngu/2019-5/5

1 - Karaganda State Technical University, Karaganda, the Republic of Kazakhstan, e-mail: vladfdemin@mail.ru 2 - Ural State Mining University, Ekaterinburg, Russian Federation, e-mail: dentalia@mail.ru

\section{STUDYING COAL SEAM BEDDING TECTONIC BREACH IMPACT ON SUPPORTING PARAMETERS OF MINE WORKINGS WITH ROOF BOLTING}

Purpose. Developing technological solutions for strengthening the weakened zone of rocks when crossing the tectonic breach zone by development workings (before entering and after exiting the breach) ensuring increased stability of rocks and reducing outburst risk.

Methodology. Building a computational model of the unstable volume of rocks under investigation that are separated from the massif by weakening contacts, which is a mathematical representation of spatial distribution of breaches, workings, layers of rocks and coal layers. Numerical simulation for determining the load on working supports, for assessing the state of unstable roof spans that are in the zones of influence of disturbed (weakened) zones of coal seams occurrence.

Findings. Technological solutions for metal-frame, combined supports and roof bolting for workings with different degrees of breach (weakening) of the rock massif are proposed, the expediency of driving workings through the broken areas using a combined supporting scheme with strengthening by an additional advance support is shown.

Originality. A new technological solution has been proposed for driving mine workings by mounting anchors across the intended fracture lines of the immediate roof rocks, which provides a "contoured rigid" scheme that contributes to the development of a single monolithic structure that works as a unified rock-support system in mining.

Practical value. The technology consists in the fact that development mine workings driven in the damaged reservoir are supported in front of the face by steel-polymer anchors mounted into the roof and sides of the working at the entrance, along the entire length of the zone and at the entrance and exit of the breach, which develops the zones of strengthened support and reduces defectiveness of the working contours. Strengthening the weakened zone of the massif is performed at the intersection of the tectonic breach zone by the underground mine cavity (at the entrance into the breach), in order to increase stabilization in front of the massif and reduce the outburst hazard.

Keywords: rocks, geological breaches, mining, cracks, block, anchor

Manifestations of rock pressure in the zones of geological breach impact. Technological interaction with the rock massif in the zones of geological breaches is a very complex mining engineering problem. The dynamics of the rock pressure effect in the breach zones depends on the spatial relative position of the working contour and the system of weakening surfaces developed by the disjunctive. In the areas of disjunctives under the action of the forces of rock pressure and its own weight around the workings, the rock massif is divided along the natural surfaces of weakening.

During the operation of coal mines, geological breaches play a negative role. Mining in the zones of geological breach impact always causes a violation of their rhythm, requires the use of additional organizational and technical measures, time and money spent on the transition of disturbed zones. This applies to all types of mining operations without exception: stoping, controlling rock pressure, driving workings, preventing gas-dynamic phenomena, etc.

Low-amplitude breaches are not detected by geological exploration [1]; therefore, they are not taken into account when planning mining operations. Low-amplitude breaches in

(c) Diomin V. F., Khalikova E. R., Diomina T.V., Zhurov V.V., 2019 the workings are unexpectedly revealed, and therefore they can cause a sudden collapse of lateral rocks, increased gas evolution, initiation of gas-dynamic phenomena and other complications.

From the practical point of view, low-amplitude breaches are of interest from two positions: their detecting (forecast) during mining and determining their characteristics in order to establish the degree of impact on the mining process [2].

Therefore, the purpose of scientific studies of low-amplitude breaches is establishing the patterns and characteristics of their location, characteristic features [3], state and properties of the rock massif in the zones of breach impact [4].

The list of issues studied is extremely wide, since low-amplitude breaches differ in their parameters (amplitude, angle of displacer, zone of impact), state (stress-strain, gas-dynamic) and properties (strength, structural, etc.) of the rock massif at the site of the breach impact [5].

The likelihood of the rocks and coal collapse, rock outbursts and other harmful manifestations of rock pressure depends on the type and parameters of breaches and production, their mutual orientation in the massif, the purpose of generation (long-wall face, drift in coal, crosscut, etc.), method of driving, thickness, strength and geometry of layers of rock and 
coal layers. Combinations of these factors and their parameters in the massif determine the nature of manifestations of rock pressure and, as a consequence, the different degree of danger of possible rock breaches and other phenomena [5].

The adhesion of rocks in the zones of displacers in the presence of sliding mirrors is practically absent. The surface of the displacer is the boundary dividing the massif into separate structural blocks.

The surfaces of tectonic fracture and splitting, accompanying breaches are additional loosening contacts dividing the rocks into small blocks of various shapes, with reduced adhesion between themselves, which forms conditions for eruptions and collapses into the working of tectonically broken, often crushed, coal from disjunctive zones with associated enhanced gas emission. Following the coal rushes, rocks can collapse in the workings.

This factor has a great impact on the conditions for stoping and driving capital and development workings in the zones of discontinuous geological disturbances.

The tensile strength of sedimentary rocks is 12 or more times lower than their uniaxial compressive strength. The tensile strength of rocks is even lower in the presence of contacts of strata, according to which sedimentary rocks are stratified over time, sometimes under their own weight.

The surface of the working roof that undercuts the rock massif experiences tensile forces.

Stability of the roof is sharply reduced with increasing the width of the working production in rough.

In cases when a bursting fault with fractured rocks adjacent to it lies in the roof of the working, its stability drops sharply. Under certain conditions, under the action of the forces of rock pressure and its own weight, massive rock caving occurs with forming domes up to $10 \mathrm{~m}$ and more in height.

The lateral surfaces of the working also experience tensile forces due to concentration of the reference pressure and tend to shift towards the working formed in the massif.

Stability of the working side in the presence of a fracture displacer, a coal seam or a hard contact of the bedding decreases.

The lying wall of the working also experiences tension and is prone to swelling in the case of weak rocks occurrence, beds or inter-seams of coal in it. In the presence of a displacer in the working lying wall, swelling of rocks is also not excluded, which was not observed in normal conditions of driving a working at a given depth from the surface.

In the roof of the working, with increasing the angle of incidence of the layers, the volume of rocks separated by weakening contacts from the massif increases, increasing the load on the workings support several times. Consequently, the risk of collapse increases.
In the sides of the workings increasing the volume of unstable rocks limited by weakened contacts and disjunctives, occurs with decreasing their angles of incidence. Under the impact of rock pressure, these volumes of rocks in the form of wedges, prisms are shifted in the direction of the working exerting intense lateral pressure [6].

Unstable rock volumes, separated from the massif by weakening contacts, can be established by building a graphicanalytical model of the studied massif volume, which is a mathematical expression of the spatial distribution of breaches, workings, layers of rocks and coal layers [7].

Below are the results of analytical studies for determining the load on the support, the estimation of the working contours located in a weakened (disturbed) zone [8].

The mechanism of rock pressure manifestation in the zones of disjunctives. Rock pressure manifestation in the zones of disjunctives was studied by the example of the Saranskaya mine of the Karaganda coal basin. Fig. 1, $a$ shows the situation along the $7^{\text {th }}$ western conveyor crosscut of the $K_{10}$ seam at the Saranskaya mine, and Fig. 1, $b$ shows the stratigraphic columns of the enclosing rocks of the $K_{10}$ seam.

There are stipulated technological measures for safe performing mining operations when driving the $7^{\text {th }}$ western $K_{10}$ conveyor crosscut in the zone of unstable rocks $(\mathrm{PC} 43+5-$ $-53+5)$.

In the danger zone, the face is provided with a minimum stock of materials: for the erection of the advance support (AMB-22 anchors $2.4 \mathrm{~m}$ in length, $30 \mathrm{pcs}$.); for strengthening the roof and the chest of the face rocks (wooden anchors, 21 pcs., PUR (polyurethane ampoules) cartridges, 70 pcs.).

When the stope face moves up to $0.5 \mathrm{~m}$ due to the rock massif delamination, the stope face is strengthened by means of using wooden anchors.

When the roof is unstable (formation of domes above the support is more than $0.5 \mathrm{~m}$ ), additional anchors are mounted (at least 4 pcs.) in the bottom-hole part in advance, with a 1 meter advance under the profile with the use of advance support.

If the rocks inrush from the roof, the working is supported by a combined (mixed) support using two KMP A3-17.2 $\mathrm{m}^{2}$ frames and 17 steel-polymer anchors for 1 running $m$ with the constant advance mounting of anchors.

In hazardous areas of unpredictable low-amplitude geological breaches, in addition to preventing the collapse of roof rocks in the face, the backlog of the support from the face in all technological cycles should not exceed $1.0 \mathrm{~m}$. If it is needed to increase the deviated section to $1.0 \mathrm{~m}$ (with the stope face delamination), there is performed chemical strengthening based on reinforcement. The role of reinforcement is played by boreholes filled with hardening compositions with placed wooden
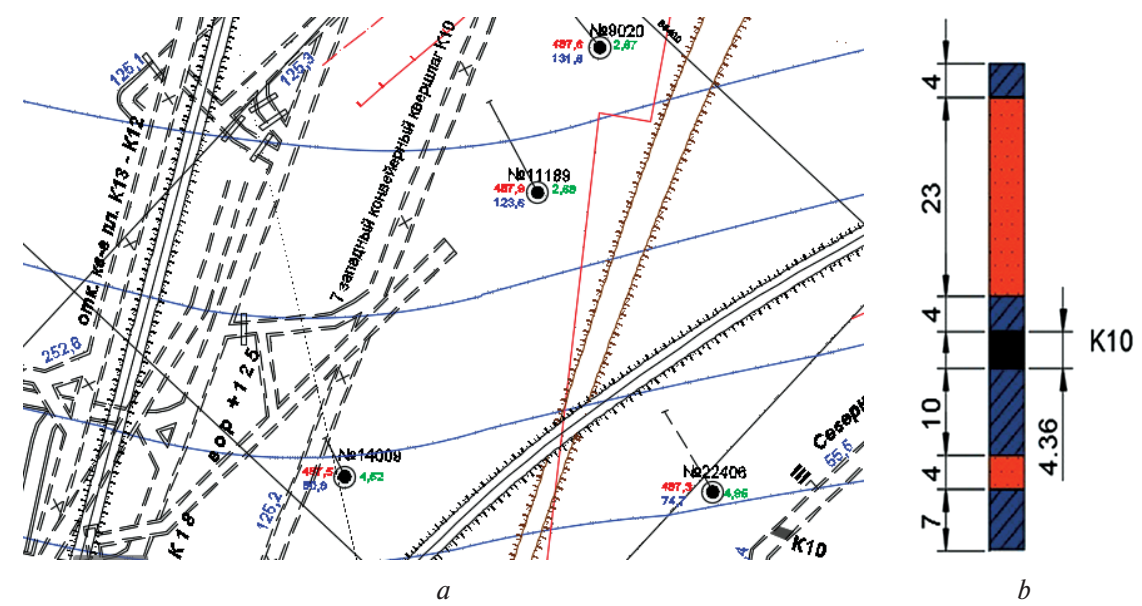

Fig. 1. The situation at the $7^{\text {th }}$ western conveyor crosscut of the $K_{10}$ seam:

$a$ - mine workings plan; $b$ - stratigraphic column of the $K_{10}$ seam (dimensions in meters) 
anchors $3.0 \mathrm{~m}$ long every $2.0 \mathrm{~m}$ of the development to strengthen the stope face.

Technological measures for safe carrying out of mining operations when driving the $7^{\text {th }}$ western conveyor cross-cut $K_{10}$ (2 district) in the dangerous zone of geological breach $H=$ $=1.5 \mathrm{~m}($ PK53 +7$)$ provide for the following: when crossing the geological disturbance displacer and the normal distance from the displacer $3.0 \mathrm{~m}$, the working is driven with strengthening the roof with the chemical composition of BevedolBivedan. Strengthening the roof rocks is to be carried out every $3 \mathrm{~m}$ of penetration into bore-holes of at least $3.0 \mathrm{~m}$ length, the injection of the bonding resin composition is to be carried out after mounting the roof bolting through the injection molding anchors "IRMA" using a DP-40 pump unit. Each injection cycle should be carried out in at least three injection anchors placed at the distance of 1.5-2.0 $\mathrm{m}$ from each other; in the dangerous zone of the geological breach the working supporting should be performed with the combined support KMPA3-17.2 with mounting 2 frames and 17 anchors AMB-22 $2.4 \mathrm{~m}$ long for 1 running $\mathrm{m}$, all the anchors should be mounted with the deviation for the face of $20-25^{\circ}$; when the domes are formed, they should be drilled with AMB-22 anchors $2.4 \mathrm{~m}$ long; to mount arched support frames, and then to lay the dukeys between the frame tops and the massif with the dukeys behind the face not more than $2.0 \mathrm{~m}$; in case of an unstable roof, to drill additional anchors (at least 5 pieces) in the bottom-hole part in advance, ahead of penetration under the interlayer with the use of the advance support. If necessary (with increasing the deviation section up to $0.5 \mathrm{~m}$ due to the delamination of the stope face) chemical strengthening is performed on the basis of reinforcement, the role of reinforcement is played by the holes filled with hardening compositions with placement of wooden anchors $3.0 \mathrm{~m}$ long every $2.0 \mathrm{~m}$ with strengthening the stope face with wooden anchors.

Fig. 3 shows the technology of the chemical strengthening of the roof, excavating and supporting the contours at half the width of the tunneling cycle and the entire width, respectively. Fig. 2 shows the technology of the chemical strengthening of the roof of the $7^{\text {th }}$ western conveyor crosscut on the $K_{10}$ seam.

The described production measures are financially costly, laborious and reduce the rate of development.

Fig. 3 shows the designing scheme of the model of the contour coal-rock massif [9].

Studying the deformation pattern at various coefficients of the rock massif weakening. For the mines of the Karaganda coal basin the use of technological schemes is typical, which in the specific mining and geological conditions provide the lowest costs of mining, the optimal speed of penetration and the high level of productivity of miners.

For supporting mine workings there are used metal-frame, combined supports and roof bolting, ensuring the lowest costs for driving and supporting the workings, taking into account the possibility of reusing the materials.

The simulation was performed using the ANSYS software package with building a computational model of the rock massif around the mine workings [10], divided into finite elements (Fig. 4) [11]. The mining site of the $7^{\text {th }}$ western conveyor crosscut of the $K_{10}$ seam of the Saranskaya mine was considered as an object of modeling.

The dynamics of the displacements growth along the axis in the vertical plane $\mathrm{Y}$ with metal-frame, combined and anchor supporting of the workings at various coefficients of weakening of the rock massif $(0.76 ; 0.54$ and 0.35 is the reduction of enclosing rocks strength). The most preferred form and type of support in the zone of influence of the normal coal seam bedding to the impaired one are arched or mixed with side anchors (with the first level steel-polymer and the second level rope anchors), at which lower stresses and displacements occur in the enclosing rocks. With increasing the depth of the development (more than $500 \mathrm{~m}$ ) this is visible, since stresses and deformations of the soil are significant, and in the roof they are not significant.
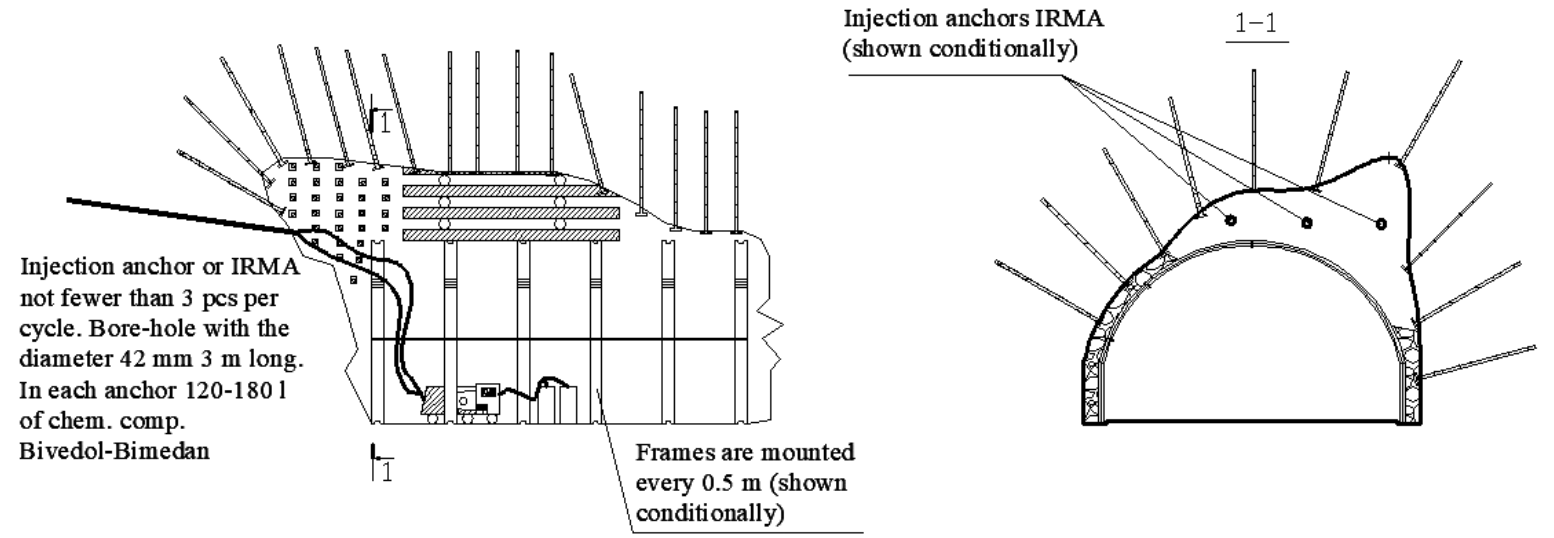

Fig. 2. Technology of chemical strengthening of the roof of the $7^{\text {th }}$ western conveyor crosscut at the $K_{10}$ seam

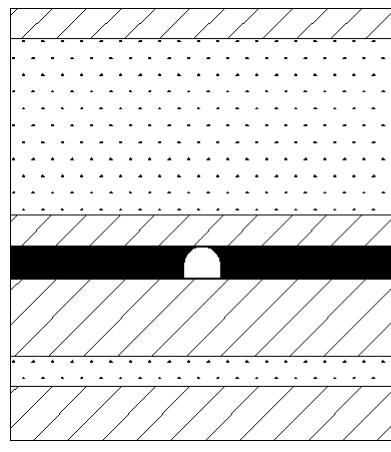

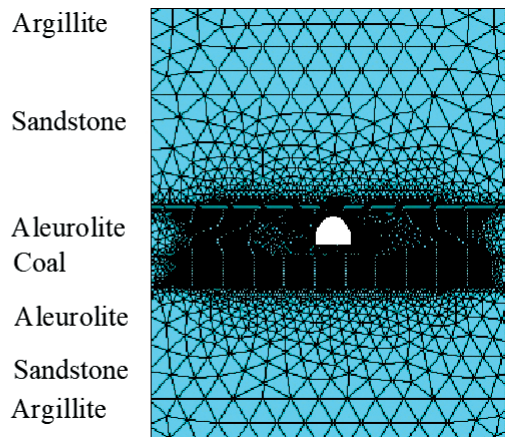

$b$

Fig. 3. Designing scheme of the contour coal-rock massif model (a); divided into finite elements (b) 

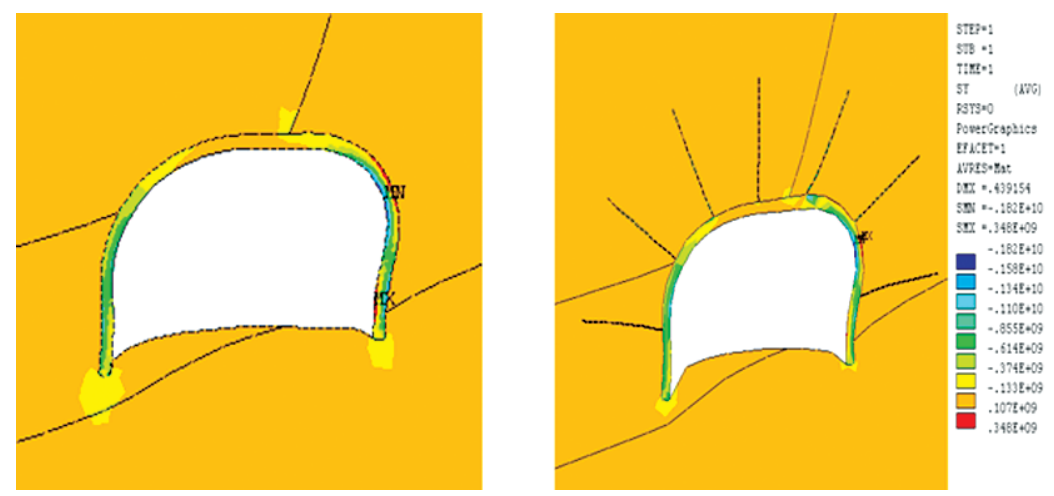

$a$
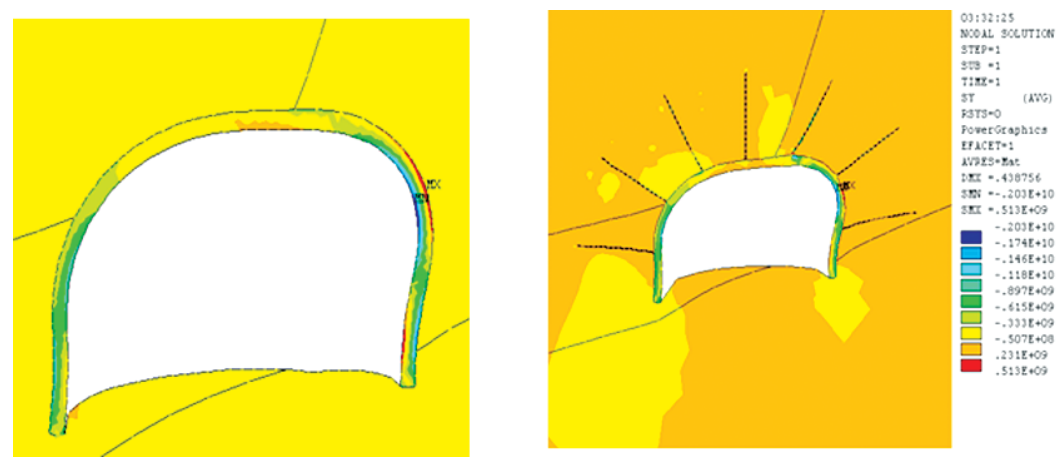

$b$
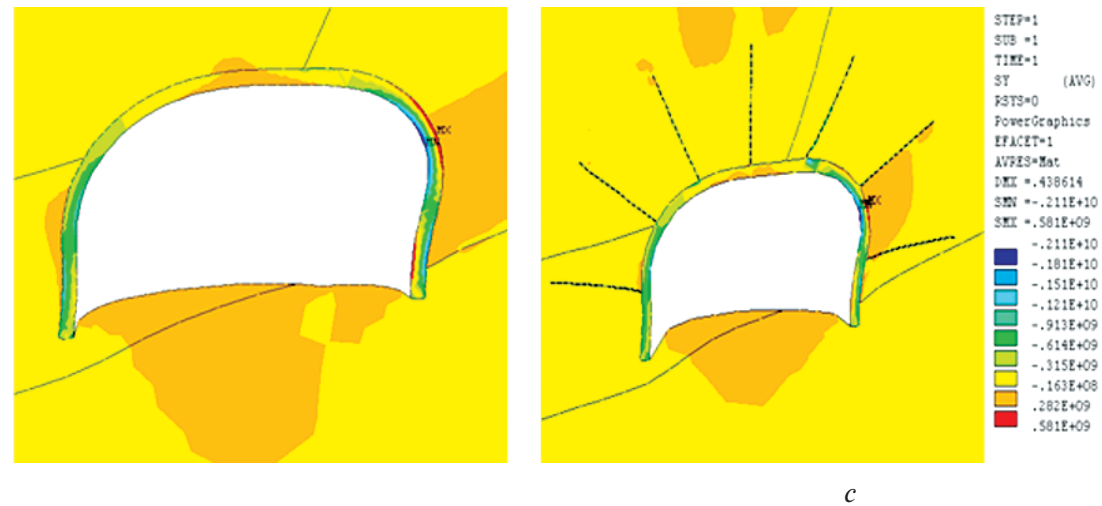

2
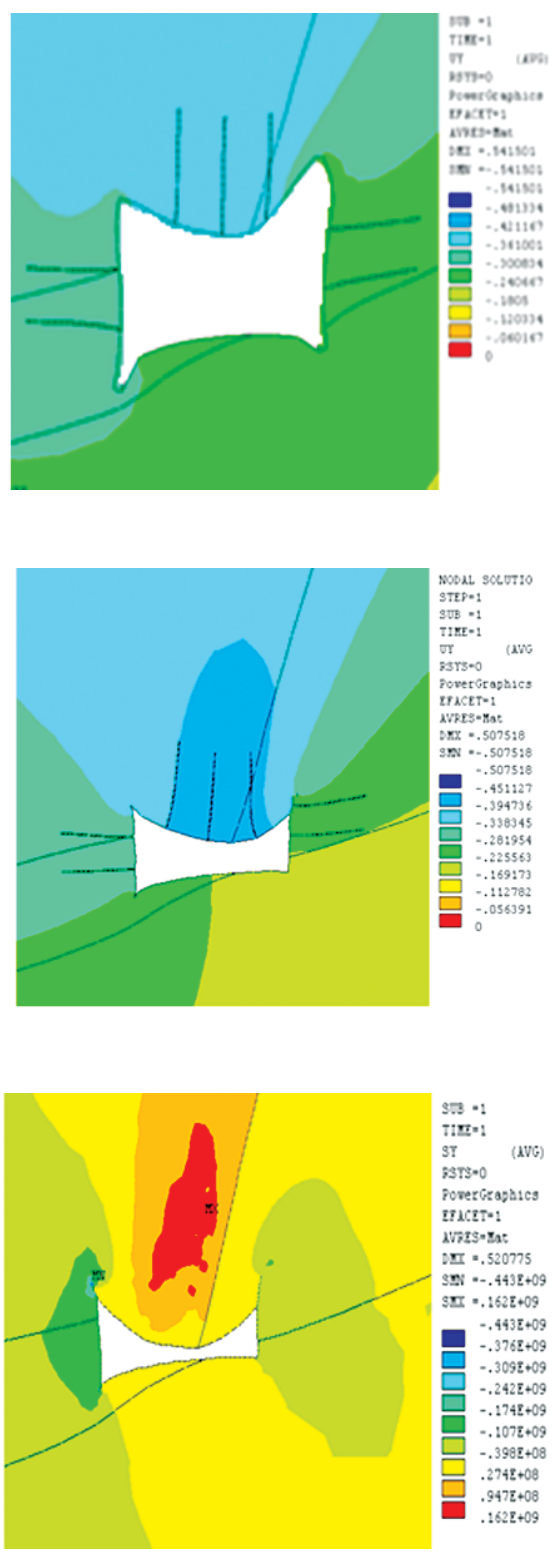

3

Fig. 4. Dynamics of changing vertical displacements (m) with the metal-frame (1), combined (2) and roof bolting (3) supporting the workings with different degree of the rock massif violation:

$a, b, c-$ coefficients of the rock massif weakening, respectively equal to 0.76; 0.54 and 0.35
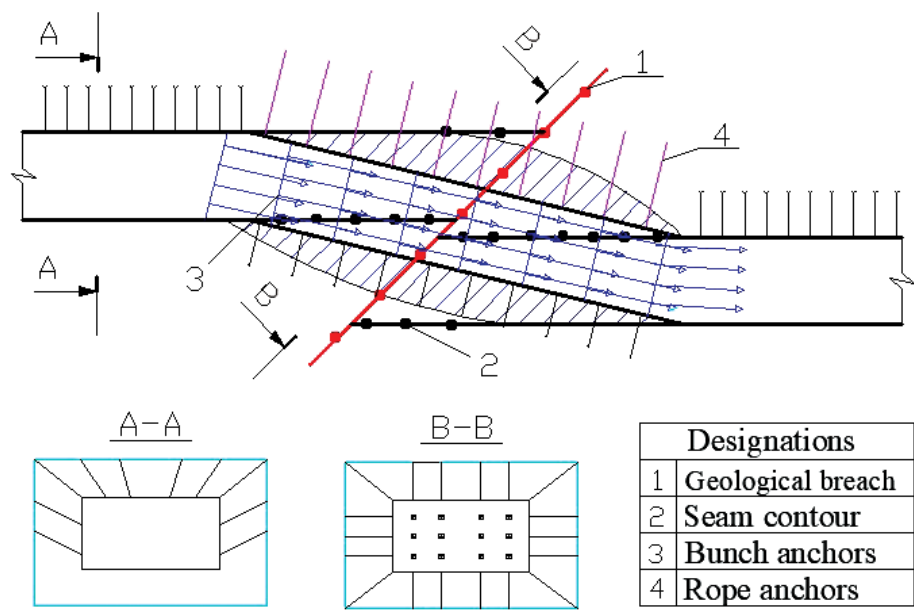

\begin{tabular}{|l|l|}
\hline \multicolumn{2}{|c|}{ Designations } \\
\hline 1 & Geological breach \\
\hline 2 & Seam contour \\
\hline 3 & Bunch anchors \\
\hline 4 & Rope anchors \\
\hline
\end{tabular}

Fig. 5. Scheme of passing through the disjunctive, weakened zone 
According to Fig. 4, comparing vertical stresses and displacements with different types of support, it can be concluded that vertical stresses in Fig. 4, 2 are much lower than those presented in Figs. 4, 1 and 3.

The dynamics of changes in vertical displacements with the metal-frame, combined supports and the roof bolting at various weakening coefficients of the rock massif shows the expediency of driving the workings through the broken areas using the combined support scheme. With a pure roof bolting with significant breaches the working is subject to increased deformations that can be reduced only when using a combination of organ frame and bush arched rows or friction racks.

According to the results of the studies, there has been developed a scheme of passing through the disjunctive (discontinuous), weakened zone, presented in Fig. 5.

The use of the developed schemes for zones with weakened rocks [12] is performed in such a way:

- a mine underground cavity made in the weakened zone, is supported in front of the face across the supposed fracture lines [13] of the massif above the working by the rods fixed with polymers around the contours in the weakened zone, which forms the effect of the preliminary impact effect and provides a stable support for the mine cavity [14];

- there is performed a preliminary reinforcing effect on the weakened massif [15].

Conclusions. When mounting the roof bolting across the intended fracture lines of the overlying massif, a "rigid" scheme is provided to facilitate the development of a single monolithic slab working as a single "rock-support" system when carrying out stoping operations.

The main impact on the nature of forming the zones of rock deformation is rendered by hardness, thickness of the roof layers contacting with the support, as well as the type of support used.

The dynamics of changing vertical displacements with metal-frame, combined supporting and roof bolting for workings with various degrees of the rock massif breaches, shows the expediency of the heading through weakened areas with the use of a combined supporting scheme with reinforcement by an additional advance support.

The preliminary supporting of the destroyed massif when underground mine cavity passes through it (including near and at the exit from the breach) ensures reducing the working cavity contours defectiveness.

\section{References.}

1. Rosenbaum, M.A., \& Demyokhin, D. N. (2014). Determination of deformation criteria for the stability of rock and roof support. Physico-technical problems of mining, (20), 82-87.

2. Kuzmin, S.V., Salvasser, I.A., \& Meshkov, S.A. (2014). Mechanism of rock "SUEKKuzbass" JSC. Mining information and analytical bulletin (scientific and technical journal), (3), 120-126.

3. Lushnikov, V. N., Eremenko, V. A., \& Sandy, M. P. (2014). Fastening of mine workings in conditions of deformable and shock-hazardous rock massifs. Mining Journal, (4), 37-43.

4. Zubov, V. P., \& Smychnik, A. D. (2017). Exploration method of potash and magnesium salts of the complex structure at great depths. Eco. Env. \& Cons., 23(3), 1697-1701. ISSN 0971-765X.

5. Demin, V. F., Nemova, N.A., Demina, T.V., \& Zeytinova, Sh. V. (2016). Control over geomechanical processes intended to impruve a coal-and-rock massif stability. Naukovyi Visnyk Natsionalnoho Hirnychoho Universytetu, 2, 5-10.

6. Federal norms and rules in the field of industrial safety "Instructions for the calculation and use of anchor lining in coal mines". (2013). Retrieved from http://docs.cntd.ru/document/499066486.

7. Demin, V.F., Nemova, N.A., Demina, T.V., \& Karatayev, A. D. (2015). Deformation of the enclosing rocks around the mine workings, depending on the influencing factors.
Naukovyi Visnyk Natsionalnoho Hirnychoho Universytetu, 4, 35-38.

8. Lushnikov, V. N., Eremenko, V.A., Sandy, M. P., \& Kosyreva, M.A. (2017). The choice of anchor support for workings, traversed in mines prone to mountain impacts. Physico-technical problems of the development of useful fossils, (3), 86-96.

9. Demin, V.F., Yavorsky, V.V., \& Demina, T.V. (2015). Character of a stressed-deformed state of a massif of breeds around anchoric fasteners. International Journal of Applied and Fundamental Research, (7-2), 201-204.

10. Zhukov, E. M., Kropotov, Yu. I., Luginin, I. A., \& Poloshkov, S. I. (2016). Classification of cracks and delamination of roof rocks according to the degree of danger from the point of view of the possibility of roof collapse in mine workings. Young Scientist, 2(106), 142-146.

11. Zubov, V. P., Fedorov, A. S., \& Bostandzhiev, D. S. (2017). Improving the efficiency of the development of formations of close formations at promising mines of Kuzbass. In Industrial safety of enterprises of mineral complex in the $21^{\text {st }}$ century, 2. Mountain newsletter (pp. 42-49). M.: Mountain book.

12. Kazanin, O. I., Sidorenko, A. A., Ermakov, A. Yu., \& Vanyakin, O. V. (2015). Investigation of the influence of zones of high rock pressure on the performance of long stoves during the development of suites of coal seams. Mining information and analytical bulletin (scientific and technical journal), (4), 2125 .

13. Lobkov, N. I., Mayevsky, V.S., Lobkov, A.A., \& Klochko, I. I. (2015). Investigation of changes in the stress state of the roof rocks ahead of the clearing face. Problems of Mining Pressure, 1(26), 47-55.

14. Seryakov, V. M. (2014). On the effect of elastoplastic deformation of microlayer contacts on the stress state of host rocks in the vicinity of the developed space. Interexpo Geo-Siberia, (4), 184-188.

15. Zubov, V. P. (2018). Modern technology and relevant problems of resource with underground mining of bedded deposits of minerals. Mining journal, (6), 77-82.

\section{Дослідження впливу тектонічних порушень залягання вугільного пласта на параметри кріплення гірських виробок 3 анкерним кріпленням}

$$
\begin{gathered}
\text { В.Ф. Дьомін }{ }^{1} \text {, Е.Р.ХАлікова }{ }^{1} \text {, Т. В. Дьоміна }{ }^{2} \text {, } \\
\text { В. В. Журов } 1
\end{gathered}
$$

1 - Карагандинський державний технічний університет, м. Караганда, Республіка Казахстан, e-mail: vladfdemin@ $\underline{\text { mail.ru }}$

2 - Уральський державний гірничий університет, м. Єкатеринбург, Російська Федерація, e-mail: dentalia@mail.ru

Мета. Розробка технологічних рішень щодо зміцнення ослабленої зони гірських порід при перетині зони тектонічного порушення підготовчою виробкою (до входу та виходу з порушення) для забезпечення підвищення стійкості гірських порід і зниження викидонебезпеки.

Методика. Побудова розрахункової моделі досліджуваного нестійкого обсягу порід, що відокремлюються від масиву контактами ослаблення, яка є математичним виразом просторового розміщення порушень, виробок, шарів порід і пластів вугілля. Чисельне моделювання із визначення навантажень на кріплення виробок, оцінки стану нестійких прольотів покрівлі, що знаходяться в зонах впливу порушених (ослаблених) зон залягання вугільних пластів.

Результати. Запропоновані технологічні рішення при металорамному, комбінованому та анкерному кріпленні виробок за різного ступеня порушеності (ослаблення) гірського масиву. Показує доцільність проходки виробок 
крізь порушені ділянки з використанням комбінованої схеми кріплення з посиленням додатковим випереджаючим кріпленням.

Наукова новизна. Запропоновано нове технологічне рішення при проходці гірничих виробок за рахунок вставлення анкерів хрестом передбачуваних ліній розлому порід безпосередньої покрівлі, що забезпечує „контурну жорстку“ схему, яка сприяє створенню єдиної монолітної конструкції, що працює при веденні гірських робіт як єдина система „порода - кріплення“.

Практична значимість. Технологія полягає в тому, що підготовча гірнича виробка, яка проводиться по порушеному пласту, кріпиться попереду фронту вибою контурними сталеполімерними анкерами, що встановлюються в покрівлю й боки виробки на вході, по всій довжині зони й на виході із порушення, що створює зони посиленого кріплення та знижує дефектність контурів виробки. Проводиться випереджальне зміцнення ослабленої зони масиву при перетині зони тектонічного порушення підготовчою виробкою (до входу в порушення), для підвищення стабілізації попереду розташованого масиву та зниження викидонебезпеки.

Ключові слова: гірські породи, геологічні порушення, гірнича виробка, тріщини, блок, анкер

\section{Исследование влияния тектонических нарушений залегания угольного пласта на параметры крепления горных выработок с анкерной крепью}

$$
\begin{gathered}
\text { В.Ф. Демин }{ }^{1} \text { Э. Р. Халикова }{ }^{1} \text {, Т. В. Демина } \\
\text { В. В. Журов }
\end{gathered}
$$

1 - Карагандинский государственный технический университет, г. Караганда, Республика Казахстан, е-mail: vladfdemin@mail.ru

2 - Уральский государственный горный университет, г. Екатеринбург, Российская Федерация, e-mail: dentalia@ $\underline{\text { mail.ru }}$

Цель. Разработка технологических решений по упрочнению ослабленной зоны горных пород при пересечении зоны тектонического нарушения подготови- тельной выработкой (до входа и на выходе из нарушения), обеспечивающей повышение устойчивости горных пород и снижения выбросоопасности.

Методика. Построение расчетной модели исследуемого неустойчивого объема пород, отделяемых от массива контактами ослабления, которая является математическим представлением пространственного размещения нарушений, выработок, слоев пород и пластов угля. Численное моделирование по определению нагрузок на крепи выработок, оценки состояния неустойчивых пролетов кровли, находящихся в зонах влияния нарушенных (ослабленных) зон залегания угольных пластов.

Результаты. Предложены технологические решения при металлорамном, комбинированном и анкерном креплении выработок при различной степени нарушенности (ослабления) горного массива, показана целесообразность проходки выработок через нарушенные участки с использованием комбинированной схемы крепления с усилением дополнительной опережающей крепью.

Научная новизна. Предложено новое технологическое решение при проходке горных выработок за счет установки анкеров вкрест предполагаемых линий разлома пород непосредственной кровли, которая обеспечивает „контурную жесткую“ схему, способствующей созданию единой монолитной конструкции, работающей при ведении горных работ как единая система „порода - крепь“.

Практическая значимость. Технология заключается в том, что подготовительная горная выработка, проводимая по нарушенному пласту, крепится впереди фронта забоя контурными сталеполимерными анкерами, устанавливаемыми в кровлю и бока выработки на входе, по всей длине зоны и на входе и выходе из нарушения, что создаёт зоны усиленного крепления, и снижает дефектность контуров выработки. Производится опережающее упрочнение ослабленной зоны массива при пересечении зоны тектонического нарушения подземной шахтной полостью (при входе в нарушение), для повышения стабилизации впереди расположенного массива и снижения выбросоопасности.

Ключевые слова: горные породы, геологические нарушения, горная выработка, трещины, блок, анкер

Рекомендовано до публікації докт. техн. наук T. К. Ісабеком. Дата надходження рукопису 16.02.19. 